Mann A (2016) The anatomy of copyright law in Scotland before 1710. In: Alexander I, GómezArostegui HT (ed.). Research Handbook on the History of Copyright Law. Research Handbooks in Intellectual Property, Cheltenham (UK), Northampton Massachusetts (USA): Edward Elgar, pp. 96118.

http://www.e-elgar.com/shop/the-history-of-copyright-law

This material is copyrighted and any download is for personal use only. 


\title{
The Anatomy of Copyright Law in Scotland before 1710
}

\author{
Alastair J Mann
}

\section{Beginning of the end - the end of the beginning}

In 1707, when Scotland joined with England in parliamentary union, a partnership was joined both political and economic. Setting aside a few temporary taxation exemptions for Scotland, economic union with England meant a shared currency, common weights and measures and standardised customs and duties, but more significantly, as confirmed in article IV of the Treaty of Union, 'full freedom and intercourse of trade'. ${ }^{1}$ Scotland had helped create the largest free trade area in western Christendom. While one of the temporary exemptions agreed for Scotland was from English duties on stamped paper, a brief advantage for the book trade in the north, the regulation of that trade and of copyright was unmentioned; by omission, the status quo ante would prevail. Given the depredations of Anglo-Scottish copyright litigation from Tonson $v$. Walker in 1739 to the more 'infamous' Donaldson $v$. Becket in 1774 perhaps it is as well that such a topic was set aside. ${ }^{2}$ Such controversy might

\footnotetext{
${ }^{1}$ K.M. Brown et al, The Records of the Parliaments of Scotland [RPS], [www.rps.ac.uk], (University of St Andrews, National Records of Scotland 2008-15),[RPS], (all following RPS references accessed on 15 March 2015), RPS , 1706/10/257 'Act ratifying and approving the treaty of union of the two kingdoms of Scotland and England' as approved 16 January, 1707.

2 Alastair J Mann, "“A Mongrel of Early Modern Copyright': Scotland in European Perspective"” in Ronan Deazley, Martin Kretschmer and Lionel Bently (eds.), Privilege and Property: Essay on the History of Copyright (Open Book, 2010), 65. There are many accounts of this, but for a sharp, recent rendering from a Scottish perspective see Warren McDougall, 'Copyrights and Scottishness', in Stephen W. Brown and Warren McDougal (eds.), The Edinburgh History of the Book in Scotland, volume 2: Enlightenment and Expansion, 1707-1800 (Edinburgh University Press, 2012), 23-39 and McDougall, 'Copyright Litigation in the Court of Session, 1738-1749 and the Rise of the Scottish Book Trade', Edinburgh Bibliographical Society, v, prt.5 (1987), 2-31. See also Richard B Sher, 'Corporatism and consensus in the late eighteenth -century book trade: the Edinburgh Booksellers' Society in Comparative perspective', Book History, 1 (1998), 32-93; Richard S. Thompson, 'Scottish Judges and the Birth of British Copyright', Juridical Review, (1992), 18-42; and Hector L. MacQueen, Copyright, Competition and Industrial Design, 2nd edn, Hume Papers on Public Policy, III, 2, (Edinburgh University Press, 1995), 1-6. For English accounts see John Feather, 'The Publishers and the Pirates: British Copyright Law in Theory and Practise, 1710-1775', Publishing History, 22. (1987), 5-32; Feather, A History of British Book Publishing (Croom Helm, 1988, Routledge, 2006), 76-83, and Feather, Publishing, Piracy and Politics: An Historical Study of Copyright in Britain (Mansell, 1994), 64-96.
} 
have delayed a vital treaty that for many secured religion and security. The Statute of Anne of 1710 was intended, of course, to fill the regulatory void, yet by then that void had become a vacuum with the demise of the Scottish Privy Council in 1708, as well as pressure from an English book trade smarting at the opportunism of Scottish books entering the English market. In fact the Scottish Privy Council had enormous significance for the history of copyright in early modern Scotland. Although secured in the Treaty of Union it became the victim of administrative impotence during the brief Jacobite invasion scare of 1708, and also was the target of opposition Scottish politicians who wished to deliver a lethal blow to the patronage network of those in power. Thereafter Scottish copyright traditions were unleashed on perplexed English lawyers and their courts, though ultimately to the benefit of book commerce broadly and of authors who saw the recognition of their rights over those of book trade copyright holders.

\section{Legal Tradition}

Both the curious transition period from 1707 to 1710 - a 'clumsy book trade engagement and marriage' - and the history of Scottish early modern copyright for the two centuries before, require much more extensive research. Existing historiography remains thin on the ground. ${ }^{3}$ Comparisons with England and the emphasis on the eighteenth century 'battle of the booksellers', have unfortunately narrowed the focus, even though Anglo-Scottish comparative study is a necessity. In many respects Scotland's copyright foundations were built from European not 'British' materials and this is exemplified by Scots Law. Early

\footnotetext{
${ }^{3}$ For general surveys of Scotland see Alastair J. Mann's, The Scottish Book Trade 1500 to 1720: Print Commerce and Print Control in Early Modern Scotland (Tuckwell Press, 2000), chapter 4, 'Scottish Copyright Before the Statute of 1710', Juridical Review, (2000), 1, 11-25 and 'A Mongrel of Early Modern Copyright', 51-65; and for quote at 65. The only previous survey is W.J. Couper, 'Copyright in Scotland before 1709', Records of the Glasgow Bibliographical Society, 9 (1931), $42-57$ but see also Dr. John Lee, Memorial for the Bible Societies in Scotland (Edinburgh Bible Society, 1824), passim.
} 
training in the law was encouraged by Scottish legislation in the 1490s that declared that the eldest sons of men of means must familiarize themselves with Latin and law, and by the commencement of legal training at Aberdeen's King's College in the sixteenth century. Nevertheless, the tradition was for Scottish students to travel not to England but to the Continent to learn law, in particular to Leiden and Utrecht in Holland. Even after Scotland's first chair in law was introduced at Edinburgh University in 1707, a pattern of post-graduate study overseas was retained. Anglo-Scottish educational interaction had been limited since the thirteenth and fourteenth century Scottish Wars of Independence, and even after general Protestant amity broke out in the sixteenth century, confessional differences were often a barrier to Scots being educated in the southern kingdom. As a result of these cultural dynamics, Scottish lawyers become conversant with the law of Rome and conflated this with Scotland's own legal codes, as confirmed in Regium Majestatum, a Glanville-based legal manual in wide-spread use from the late medieval period, to produce the fundamentals of Scots Law. ${ }^{4}$

Three aspects arising from this emphasis are pertinent to the legal and philosophical attitudes to pre-modern Scottish copyright before 1710. Firstly, the influence of Roman Law gave Scottish jurists a passion for codification. This is seen in a sequence of early modern and modern legal treatises, notably Sir Thomas Craig's Jus Feudale (1603), James Dalrymple, Viscount Stair's Institutions of the Law of Scotland (1681) and later George Joseph Bell's Principles of the Law of Scotland (1829). Secondly, although both Scots Law and Roman law accepted the theory of 'incorporeal' rights, as seen in Justinian's Institutes, 'de rebus incorporalibis', such as, for example, in noble titles without necessarily a territorial basis, Scots interpretation appeared to abrogate the concept of 'incorporeal' property in creations or inventions. That is to say, for such 'property' to have a secure legal basis it had to have

\footnotetext{
${ }^{4}$ RPS, A1496/6/4 (13 June 1496).
} 
physical form. Thus an author's manuscript or a printed book was legal property, but not the text or its ideas. In addition, it was only illegal to 'copy' such intellectual or commercial property if a successful application was made to the appropriate licensing authority for a copyright licence or commercial patent. Thirdly, Scots Law, in theory at least, was grounded on social law and the application of 'evident utility', which interestingly is a phrase found in article XVIII of the Treaty of Union on 'the laws concerning regulation of trade'. These elements came together in a balancing of public interest and private right which saw limitations placed on the duration and extent of copyright protection in early modern Scotland. In contrast, under English Law before 1710, with its less codified, common law and more statute-focused basis, the author created property when he wrote a text, and English common law confirmed perpetual copyright as long as no statute qualified that right. ${ }^{5}$

In Scotland, however, 'reasonableness' was the test through 'evident utility. There are many cases where 'reasonableness' was the deciding factor in Scottish court judgments over copyright, and more especially before the Privy Council of Scotland. The most well known and striking of such cases arose in 1614 and concerned Andrew Hart (fl. 1589-1621), the great Edinburgh printer-bookseller of the first half of the seventeenth century. This occurred when Hart was at the height of his commercial success. The same year he published John Napier's famous mathematical text Mirifici Logarithmorum Canonis Descriptio which was read throughout Europe. Hart not only printed books but was also the largest Scottish book importer before the Restoration of 1660. He had an exotic background as a committed Presbyterian and acted as an English spy before the Union of the Crowns of 1603. In June 1614, and for a considerable sum, Hart purchased from King James VI and I (r.1567-1625) the exclusive right to print overseas and import books into Scotland. This move led to

\footnotetext{
${ }^{5}$ RPS, 1706/10/257; J. B. Moyle (trans.), The Institutes of Justinian (Clarendon Press, 1913), Book II, 2, 'Of incorporeal things'; Mann, Scottish Book Trade, 96-7 and 'Scottish Copyright Before the Statute of 1710', 13; MacQueen, Copyright, Competition and Industrial Design,1-7
} 
protests from Hart's co-religionists, the Presbyterian Edinburgh booksellers James Cathkin (fl. 1601-31) and Richard Lawson (fl. 1603-22), and the then king's printer Thomas Finlason (fl.1602-27). In a subsequent judgment on the matter, the Privy Council ruled against Hart in spite of the fact that he came to the hearing armed with a letter from the king demanding the right be confirmed 'without onye delay or impediment'. The council's judgment is a statement about liberty of trade, of executive independence from crown action and of a late renaissance commitment to literate society:

The freedom, liberty and privilege or printing, importing and selling of all such books and volumes, which are allowed and not forbidden, ought to be free to all His Majesty's subjects and not conferred and given to any one person without great hurt and prejudice to the country, because every such private freedom, liberty and privilege is not only a monopoly of evil consequence and example, but will give occasion to alter and raise, heighten and change the prices of all books and volumes at the appetite and discretion of the person and persons in whose favour the privilege shall happen to be conferred, and for this reason the said Lords ordain the gift and privilege purchased by the said Andrew Hart from the king to be halted, and in no way to be passed or expedited. ${ }^{6}$

The rejection of this privilege clearly illustrates executive views on the licensing of the press and copyright, the council being the very agency that granted copyright in Scotland. In spite of some further crown-supported pressure to secure restrictive monopolies for the post of Scottish king's printer in the 1670s, this philosophy would be reflected in the views of the Scottish Parliament in the 1670s and 1680s and also the Scottish courts.

\footnotetext{
${ }^{6}$ John Hill Brown, David Masson, P. Hume Brown et al (eds.), Register of the Privy Council of Scotland, $1545-$ 1691 (37 vols., three series) [RPCS], (Scottish Record Office, 1877-1933), i, 10, 827-8; A. J. Mann, 'Hart, Andro ( $b$. in or before 1566, $d$. 1621)', Oxford Dictionary of National Biography [ODNB] (Oxford University Press, 2004-15); online edn, Jan 2008 [http://www.oxforddnb.com/view/article/12470, accessed 15 March 2015]. Text modernised by the author.
} 


\section{'Particular' copyrights: England and Scotland}

Given the political instability of the age, it is obvious that for the governments of early modern England and Scotland the main purpose of regulation was censorship not copyright. However, frequently these different pillars of print control came together. In England, between 1566 to 1695 , most books had to be licensed jointly by a government licenser with a warden of the Stationers' Company (established by royal charter in 1557) before they could be published; they were then recorded in the Stationers' Register, as 'entered for . . . copy' of the particular book. The owner of the right to 'copy' was always the printer or bookseller who was entering the book for publication and the author was seldom even mentioned. ${ }^{7}$ In spite of English book traders and the Stationers' Company setting up a Society of Stationers in Edinburgh in the late 1630s, a venture disrupted by the Scottish Covenanting rebellion and English Civil War and abandoned in the 1660s, and also incomplete plans by the Scottish king's printer Andrew Anderson to set up an exclusive Edinburgh society in the early 1670s, no Scottish equivalent of the London Stationers' Company was ever established in the Scottish capital. ${ }^{8}$ This was a key difference in the regulation of the press and of the system of copyright registration and licensing. Both the smaller scale of the Scottish press and the medieval tradition of burghs having equal status and rights to develop commerce

\footnotetext{
${ }^{7}$ Feather, History of British Book Publishing, 21; Lyman Ray Patterson, Copyright in Historical Perspective (Vanderbilt University Press, 1968), 78-113; Mark Rose, Authors and Owners: The Invention of copyright (Harvard, 1993), 1-12; Alastair J. Mann, “'Some Property is Theft': Copyright law and illegal activity in early modern Scotland" in Robin Myers, Michael Harris and Giles Mandelbrote (eds.), Against the Law: Crime, Sharp Practice and the Control of Print, (Oak Knoll Press, British Library, 2004), 31-2. The first formal use of 'copy right' does not appear in the Company records until 1678, when it appeared in one of the Company's bylaws that prohibited members from suing in the regular courts for copyright infringement. The Orders, Rules, and Ordinances, Ordained, Devised, and Made by the ... Stationers (1692) 1, 20 (3 Jan 1677/8).

${ }^{8}$ RPCS, iii, 3, 423-5; Mann, Scottish Book Trade, 117.
} 
independently, prevented the permanent formation of a centralising society that might have acted as an intermediary between the crown and copyright holders.

Scotland's first statute that forbade unlicensed printed was to arrive in early 1552, as Protestant ideas and printings began to threaten the established order of the Church of Rome. The act 'Anent printaris' therefore prescribed that the 'ordinarie', that is the local bishop, took responsibility for licensing. ${ }^{9}$ This was a typical legislative measure and the most common method of preventive or a priori censorship in early modern Europe, although clearly an author, printer or publisher of seditious material was unlikely to submit his manuscript for the censor's approval. It is for this reason that licensing was far more significant to the 'legitimate' press and became a systemic support for copyright regulation. From the Scottish Reformation of 1560, secular crown officials and councillors rather than clergy took on the role of censors, where necessary, and also for licensing and so copyright. In sixteenth and seventeenth century Scotland, therefore, copyrights for printings sprung directly from patents granted by the crown and continued so throughout the period, when in England this practice declined, though never entirely, as registration with the Stationers' Company offered a secure means of establishing copyright protection. Meanwhile, the typical Scottish licensee was granted the 'power', 'licence', 'liberty' or 'privilege' to 'print, reprint, vend, sell and import' but not specifically 'to copy'. ${ }^{10}$ Individual Scottish book licences granted by the crown, or its representatives, usually the Privy Council, were for a limited number of years, either a specific period or the lifetime of the licence holder. Essentially like France, Spain and the Low Countries there was no Scottish notion of perpetual copyright; on the other hand, the Stationers' Company, English booksellers and even some English authors continued to claim perpetual copyright until it was quashed in the House of Lords in 1774.

\footnotetext{
${ }^{9}$ RPS, A1552/2/26 (February 1551, Old Style).

${ }^{10}$ Scottish patents for books used some or all of the terms 'power', 'licence', 'liberty' or 'privilege' with some additional variations such as 'sole liberty'. 'Privilege' and 'licence' were the most common.
} 
William Lily's Grammar, written in 1513 and first published in final form in 1542, is an extreme example of English perpetual copyright. It became a prescribed text in English schools for the next 200 years and as late as the early eighteenth century Thomas Longman acquired the profitable patent. The first Scottish 'particular' copyright is of similar vintage and stemmed from the patent granted to the printer Thomas Davidson (fl.c.1532-42) in 1541 to print for six years the acts of the Scottish Parliament. This was followed in 1559 by the remarkable eleven volume, and ten-year multi-title patent granted to the author and grammarian William Niddrie. This was a bold attempt at a school book publishing programme which did not survive the hiatus of the Scottish Reformation the following year. Nevertheless, these copyrights confirm that from the onset Scottish authors were considered on a par with any other copyright holders in Scotland. ${ }^{11}$ Also, the contrast between Niddrie (term limited) and Lily (endlessly transferrable and so unlimited) could not be starker and the test of 'reasonableness' hangs in the air.

That the English book trade got away with monopolistic tendencies may seem a surprise given the resentments that monopolies created in the late sixteenth and early seventeenth centuries. This perhaps signifies the special status sometimes attributed to intellectual property: it also had some impact on the Scottish book trade. Two types of copyright existed in early modern England, the 'printing patent', that is those copyrights granted by the sovereign, and after 1557 the Stationers' copyright; essentially the former public and the latter private. Taking the second of these first, from the 1580s onwards Stationer's guild members began a process of transfer and purchase of copyrights which facilitated their accumulation in the hands of a small group of wealthy copy holders. This process was intensified after the Union of the Crowns in 1603 as James VI and I responded to

\footnotetext{
${ }^{11}$ Registrum Secreti Sigilli regum Scotorum: Register of the Privy Seal of Scotland (printed series) (9 vols., HM General Register House, 1908-82)[RSS], RSS, ii, 653, no.4335; RSS, v. pt.1, 143-4, no.658; Mann, 'Copyright and illegal activity', 32; Feather, History of British Book Publishing, 21
} 
parliamentary anxiety over monopolies by inadvertently making them worse as far as the English book trade was concerned. James recalled and gifted to the Stationers' Company 'for the benefit of the pouer of the same' the valuable patents already granted to John and Richard Day (for primers and psalters) and to James Roberts and Richard Watkins (for almanacs and prognostications) and these patents became the legal basis for the 'English Stock', as it was known, and reenergised the frantic buying and selling of copies within the Company, concentrating patents into even fewer hands, in a narrowing 'collective monopoly' or oligarchy. Some years after, fear over monopoly trading culminated in the English Statute of Monopolies of 1624 where the Westminster Parliament limited to fixed periods patents in industrial processes and inventions. Books were excluded and of course the statute did not apply in Scotland. There, however, the terms of industrial patents and copyrights in any case shadowed each other, even though monopolies were also subjected to greater scrutiny in this period. With King James's approval the Scottish Privy Council set up a commission of grievances over monopolies in 1623, and later that year when a Standing Commission of Manufactories was established to monitor such monopolies, copyrights were not considered. In 1641 the Scottish Parliament halted some major monopolies, including those for tobacco, leather, pearling and armoury 'because of the great hurt inflated on the lieges by monopolies, all patents purchased for the benefit of particular persons in prejudice of the public', but again, like England, books were not on the agenda. ${ }^{12}$ The entire process of monopoly review and copyright trading in the Stationers' Company emphasised the increasingly perpetual nature of their copyrights compared to the fixed periods for industrial processes in both kingdoms and of copyrights in Scotland. If these nations' copyright systems were fairly similar in the mid-sixteenth century, by 1600 they were drifting further apart.

${ }^{12}$ RPCS, i, 13, 219-222, 299-302 and 240; RPS, 1641/8/192; Mann, 'Copyright and illegal activity', p. 34. 
The initial similarity between these copyright regimes needs some emphasis, however. Licences granted by the English crown, or the 'printing patent' continued throughout the early modern period in parallel with the Stationers' copyright. The first of these was granted by Henry VIII to John Rastell in 1512 for printing Thomas Linacre's Latin grammar Progymnasmata grammatices vulgaria (c.1515) a text actually in English. In Scotland meanwhile, the first royal patent was that given by King James IV (r.1488-1513) to Scotland's first printers Walter Chepman and Andro Myllar in 1507. The chief reason for granting this patent was to print a new national breviary, the Breviarium Aberdonense (1510), compiled by William Elphinstone, bishop of Aberdeen and founder of King's College Aberdeen. This text was prescribed to replace 'Sarum use', the Salisbury breviary which was the standard liturgy to this point. The patent was though a general gift listing the right to print statutes, histories and chronicles as well as the breviary, and not strictly a copyright for a single act or acts of publication, unlike Davidson's of 1541 or Niddrie's of 1559. Nevertheless, it is important to note that these two Scottish types correspond to English equivalents, the Chepman and Myllar licence-'general', for life and containing generic classes of books, and the Davidson variety_-'particular' and limited in time, in England typically to licences of seven to ten years and in Scotland to six to ten years but gravitating towards a standard period of nineteen years. ${ }^{13}$

Thus, before the Stationers' Company was well established the practicalities of copyright in England and Scotland were not too dissimilar. Indeed, such was the similarity that various English printers had since the 1580s operated in Edinburgh out of commercial opportunism or through political exile. In the reign of Charles I (r.1625-49) the Stationers of London reached deep into Scotland's public copyright regime. The so-called 'Scotch Patent', as it

\footnotetext{
${ }^{13}$ Patterson, Copyright, 86-7; RSS,i, 223 no.1546 and Dickson and Edmond, Annals of Scottish Printing, 7-8; National Records of Scotland [NRS], Privy Seal Manuscript Registers[PS] PS.1.3, 129; RSS, 2, p. 653, no. 4335; Peter W.M. Blayney, The Stationers' Company and the Printers of London, 2 vols. (Cambridge University Press, 2013), I, 166-7
} 
was known in London, was acquired as part of Miles Flesher's Stationers' Company monopoly which he built up from 1617 to 1638 . This included a share in the office of Scottish royal printer which he obtained in 1632 with his partner Robert Young, the printer of the controversial Prayer Book which sparked the Covenanting rebellion against King Charles. Ironically, Flesher had his dividend suspended by the Stationers in 1634 as a punishment for importing into England psalms produced at his Edinburgh press. ${ }^{14}$ These Englishmen lingered in Edinburgh until the late 1660s by which time the impracticality of controlling a press from the distance of London had them withdraw and a new king's printer patent, with what a contemporary described as 'exorbitant clauses', was then awarded to the Glasgow printer Andrew Anderson in $1671 .{ }^{15}$

\section{Regulation and Devolution}

Anderson's general patent was given under Scotland's Great Seal in 1671 and ratified by the Scottish Parliament in 1672, which suggests a fragmented system of regulation. In fact senior government appointments and noble titles were confirmed through both these mechanisms conflating royal wishes with political and public affirmation. Confirmation of particular copyrights was another matter entirely, however. Scottish copyright from 1507 to 1710 depended on government copyright underpinned by royal prerogative. This was the case whether licences were granted by the monarch or his or her representatives, 'the king in

\footnotetext{
${ }^{14}$ C. Blagden, The Stationers Company, $1403-1959$ (George Allen \& Unwin, 1960), 138-145; Mann, The Scottish Book Trade, 117. For reflections on the wide historiography on the Stationers' Company see, Robin Myers and Michael Harris (eds.), The Stationers' Company and the Book Trade, 1550-1990 (St Pauls, 1997); Robin Myers, The Stationers' Company Archive: an account of the records, 1554-1984 (St Pauls, 1990), xv-xvi; Robin Myers (ed.), The Stationers' Company: a history of the later years, 1800-2000 (Worshipful Company of Stationers and Newspaper Makers, 2001), 247-8 and Deazley et al (eds.), Privilege and Property, 14.

15 John Lauder of Fountainhall, The Decisions of the Lords of Council and Session from June 6th 1678 to July 30th 1712, (2 vols., Hamilton and Balfour, 1759-61), i, 205.
} 
council' or the 'king in parliament', or passing the great or privy seals. The Privy Council was the main licensing authority in the period, although there were changes in the systems of regulation. Until about 1610 copyright licences for individual books were confirmed by the royal Privy Seal, but after then and particularly from the 1660s, publishing privileges were confirmed by act of Privy Council. Thus the Privy Seal confirmed in 1599 to the bookbinder John Gibson a seven-year licence to sell an edition of the psalms printed in Middelburg, and in 1602 that the sons of the printer Robert Smyth, Robert and David, were granted twentyfive-year licences to print a range of texts, including 'Catechisms, the plane donat . . the celect and familiar epissillis of Cecero. . . the second Rudiments of Dunber, [and] the psalmes of Buchanane'. ${ }^{16}$ Subsequently, the likes of the authors David Wedderburne and Andrew Brown, for respectively a twenty-five-year licence for a new grammar in 1632 and a nineteen-year licence for Brown's medical volume A Vindicatorie Schedule about the New Cure of Feavers in 1691, were derived from acts of council. This is not about the king residing in London, and in any case there are exceptions to the chronology. After 1610 or so the Privy Seal was still employed when the monarch had a personal interest in the copyright, as in the twenty-one-year privilege granted for the catechism God and the King in 1616, a pet project of King James given its focus on obedience and royal prerogative, and the thirty-oneyear licence to Sir William Alexander (c.1567-1640) to publish in 1627 an 'official' edition of The Psalms of David which Alexander translated with the help of King James. Later in the century, the ten-year licence granted to the geographer-royal Robert Sibbald (1641-1722) in 1682 for his Scotia Antiqua and Scotia Moderna, which was subsequently published in one volume entitled Scotia Illustrata in 1684, was confirmed via the Privy Seal. ${ }^{17}$ In the seventeenth century, however, ordinary book patents followed other types of patent in the general administrative shift as a patent in brewing in 1594 was licensed under the privy seal

\footnotetext{
${ }^{16}$ NRS, PS.1.71, f.451; PS.1.73, f.8.

${ }^{17}$ RPCS, ii, 4, 500-1; iii, 16, 443-4; NRS, PS.1. 85, 254r-247v; PS.1. 100, f.305; PS.3. 3, f.450-1; RPCS, iii, 38, 423.
} 
whereas that in glass-making in 1662 was under act of Privy Council. ${ }^{18}$ This was yet another example of Scottish licensers seeing books as commercial properties to be handled like any other.

Nevertheless, an evolving sense of literary property was also becoming evident and in a manner parallel with the book markets of England and of Holland. Copyright began to be seen more as personal property rather than a gift from the crown. This is seen in the surviving registers of the Privy Council which from the 1670s reveal that almost all book licences were enacted and recorded in decreta registers (private business) with only national publishing concerns, such as Wedderburne's new national grammar in 1632, the winner of a remarkable national 'battle of the grammars' competition, being considered public business for recording in the Privy Council's acta registers. After a spell of elite recording in acta in the Restoration period, such as the licence granted to the partners Swinton, Glen and Brown to print in three simultaneous printings The Law and Customs of Scotland in Matters Criminal (1678) by the Lord Advocate Sir George Mackenzie of Rosehaugh (1636-91), when we reach the 1690s all copyrights are recorded in decreta. ${ }^{19}$ Commercial exploitation and literary property come together in what was now accepted as a private right.

This process of private and disposable printed property was further emphasised during the seventeenth century as copy holding was traded in terms not too dissimilar to London. One of the best examples of this behaviour is found in the career of Thomas Finlason, the former Dundee merchant and the last of the royal printers in Edinburgh to be gifted the position for life. Interestingly before he acquired the royal patent in 1612, and succeeded Robert Charteris (fl.1600-10), Finlason set about from 1602 to 1611 buying up the copyrights of other Edinburgh printers. These included sixteen copyrights from Robert Smyth (fl. 1582-1602),

\footnotetext{
${ }^{18}$ For a more extended list see $R S S$, viii, 70, no. 414 (coal-mine pumps); PS.1.66, ff. 107v-108r (brewing) $R P C S$, i, 12, 106 (soap-making); iii, 1, 155 (glass-making).

${ }^{19}$ RPCS, ii, 4, 168-9 and 500-1; RPCS, iii, 5, 218-9; Mann, 'Scottish Copyright', 15.
} 
purchasing his privileges, stock and equipment from Smyth's widow in October 1602 and setting up his press; nine in 1606 from the son of John Gibson (fl.1580-1600), royal bookbinder, some of which originally came into the hands of Alexander Arbuthnet (fl. 157585), co-printer of Scotland's first domestic bible, in the late 1570s, then passed to George Young, archdeacon of St Andrews in 1585, then to the bookseller Gilbert Masterton (fl.158799) to 1587 , and finally to be acquired by Gibson in 1589. It seems at each stage in the chain the copyrights increased in value. Finlason then registered some of his own copyrights in 1611. By the time he became king's printer he owned some of the most profitable copyrights in early modern Scotland, including Dunbar's Rudiments, George Buchanan's Psalms, 'Blind Hary's' The Wallace and The Works of Sir David Lindsay, along with a range of classical and vernacular works. In Scottish terms this was an impressive accumulation of copyrights and a clear competitive advantage even before he became king's printer. He also acquired the privileges and materials of the Englishman Robert Waldegrave (fl. 1590-1604), the former 'Martin Mar-prelate' puritan printer who fled England to Scottish exile, became printer to James VI, produced the king's own works, and followed him to London in 1603 only to die soon after. Finalson acquired Waldegrave's stock and copyrights from his grieving widow, a common enough event in the career of this remarkable commercial vulture. ${ }^{20}$

Given that the main copyright agency in Scotland was the crown, working through its executive arm the Privy Council, we have the impression of a highly centralised copyright regime. Nevertheless, there were other mechanisms through which copyright could be confirmed. Copyright was sometimes devolved to local agencies and in a manner not too dissimilar to the Stationers' Company. Edinburgh, or a society of its major book traders,

\footnotetext{
${ }^{20}$ Harry G. Aldis, 'Thomas Finlason and his press. With a handlist of his books', Edinburgh Bibliographical Society Publications, i, no 20 (1896). To trace this complex series of acquisitions see the patents listed in Mann, Scottish Book Trade, 235-43. For a summary of Waldegrave's career see K. S. van Eerde, 'Robert Waldegrave: the printer as agent and link between sixteenth-century England and Scotland', Renaissance Quarterly, 34/1 (1981), 40-78 and Mann, 'Waldegrave, Robert (c.1554-1603/4)', ODNB, [http://www.oxforddnb.com/view/article/28441, accessed 18 March 2015] and a forthcoming detailed study by Rebecca Emmett.
} 
never gained a regulatory supremacy over the remainder of the kingdom, as did London of course, and although printing did not commence in Aberdeen, Glasgow and Dundee until 1622, 1638 and 1703 respectively, no centralised limitation was placed on the proliferation of presses. Local town councils were authorised, as with any other commercial activity, to license and manage their local presses. ${ }^{21}$ These burgesses took responsibility to employ town printers, to supervise the appointment of college printers, not always the same as the former, and to license and censor the local press output. This local press control was occasionally ratified by the government, and at times by a variety of supplementary authorities. In 1634, for example, Charles I confirmed the power of the masters of the Old College of Aberdeen to censor the output of the local press, and fifty years later the Privy Council ruled that the Aberdeen, Glasgow and Edinburgh presses could not operate without license 'from the Bishop of the dioces for any thing in divinitie' and without reference to the appropriate medical, legal and, if necessary Privy Council authorities, for specific genre. These were measures driven as much by censorship as by copyright and qualitative considerations. Copyright was also a factor, however. After the Restoration the 'printing burghs' gave local copyright protection for a variety of burgh almanacs, diurnals, newssheets and newspapers, such as Aberdeen Town Council's licensing and protection of the Aberdeen almanac from the 1660 s. $^{22}$

'Local copyright', therefore, existed on a private basis by authority of the magistrates of burgh corporations. Often this merely represented a licence to print rather than a specific term, yet it was copyright nevertheless. Many local printings were in any case either ephemeral or of insufficient value to necessitate a proprietary approach. Almanacs and

\footnotetext{
${ }^{21}$ For the establishing of these burgh presses see Mann, The Scottish Book Trade, 7-12.

${ }^{22}$ Extracts from the Records of the Burgh of Aberdeen, [ABR] John Stuart (ed.), (2 vols. Scottish Burgh Record Society, 1871-2), 1, 245-6, and J.P. Edmond, The Aberdeen Printers, 1620 to 1736, (J \& J.P. Edmond \& Spark, 1884-6), pp. xiv, xxxi; J. MacLehose, The Glasgow University Press, 1638-1931 (MacLehose, 1931), 61; Mann, Scottish Book Trade, 102-3.
} 
newspapers were, though, considered the most valuable properties, especially from the Restoration. The Privy Council granted licences for local news-sheets or diurnals, as well as newspapers, such as the patent for a weekly diurnal awarded to the Edinburgh news editor and postmaster Robert Mein in 1661, and that to the news publisher James Donaldson for the Edinburgh Gazette in 1699, Scotland's first regular newspaper with some longevity. Nevertheless, local licensing in this field could arise when the central authorities were 'distracted' or slow to respond. In 1657, for example, during the licensing uncertainties of the Cromwellian period, Aberdeen council licensed the town printer John Forbes to produce a weekly diurnal 'for the use of the inhabitants'. Also, in the early eighteenth century the Edinburgh town council found it necessary to license newspapers during the two-year hiatus between 1708 and 1710, including the Scots Postman to David Fearn (1709) and the Edinburgh Courant to the ubiquitous English propagandist Daniel Defoe (1710). ${ }^{23}$ Of even greater commercial value than newspapers, before the Edinburgh Gazette and those that followed on, were the burgh almanacs, printed annually but to very large print runs of up to 50,000. The magistrates of Edinburgh, Glasgow and Aberdeen each licensed burgh printers to produce their respective almanacs and took considerable steps to protect the local monopoly and rights beyond the city boundaries. In October 1667 the chapman Alexander Gray was found to be selling 'alien' almanacs in Aberdeen. When the burgh printer, John Forbes, the elder (fl. 1656-75), protested over this the council took action to safe-guard the 'Aberdeen almanac' within the burgh, censuring Gray and prohibiting the sale of all except the Forbes edition within the burgh. Also, in November 1684, the Edinburgh magistrates took

\footnotetext{
${ }^{23}$ RPCS, iii, 1, 115; NRS, Manuscript Privy Council Registers, PC. 2, 28, ff. 366r-366v; ABR, 2, $165-6$ (29 July, 1657); J.D. Marwick, M. Wood and H. Armet (eds.), Extracts from the Records of the Burgh of Edinburgh [EBR] (13 vols. 1573-1718) (Oliver and Boyd, 1867-1967), 13, 183 (1 February, 1710); 'Copyright before $1709^{\prime}, 46$.
} 
action to protect from counterfeit editions the Edinburgh almanac written by the mathematician James Paterson. ${ }^{24}$

The one body not yet considered that occasionally granted a copyright was the Scottish Parliament itself. As with the government on a day-to-day basis, it mostly regulated censorship providing a legislative framework for censors, yet it also ratified the general gifts to king's printers, and authorised and licensed the more prestigious or national publishing activity. This included prescribed national publications such as the Directory of Public Worship introduced by the Covenanters in 1645 and even prestigious legal texts as in 1633 , when Parliament, in the presence of Charles I, agreed that Robert Craig, son to jurist Sir Thomas Craig (1538-1606), be licensed for twenty-one years to print in three volumes his father's great treatise on Scottish land law Jus Feudale. A committee appointed to oversee the printing was headed by Charles I's Lord Advocate, Thomas Hope of Craighall (c.15861643), himself a significant published jurist. This publishing venture was of long duration and the first printing did not appear until the Edinburgh edition of $1655 .{ }^{25}$ Until then Craig's book circulated in numerous manuscript copies showing that to the legal profession manuscript circulation was of great significance well into the Restoration period. No evidence has yet been found of a debate over manuscript copyright.

The London Stationers' Company is remarkable for its record keeping but the same cannot be said of the recording of copyrights in Scotland. Historians have to dig deep into the many volumes of state and local records. Nevertheless, there is evidence that a procedure of maintaining a register of patented books occurred sporadically, even though such registers remain lost to us. In July 1574, during the regency of James Douglas, earl of Morton, when

\footnotetext{
${ }^{24}$ Aberdeen Council Records [ACR], 55, f.66-7; EBR, xi, 128; Edmond, Aberdeen Printers, xlv (30 October 1667). For an excellent summary of Scottish almanacs see William R. MacDonald, 'Scottish SeventeenthCentury Almanacs', The Bibliotheck, iv, pt. 1.8 (1966), 257-322.

${ }^{25}$ RPS, 1645/1/65 ( 6 February, 1645); RPS, 1633/6/65 (28 June, 1633) [accessed March 2015]; Mann, Scottish Book Trade, p. 50; States papers and miscellaneous correspondence of Thomas Earl of Melrose ed. James Maidment, (2 vols, Abbotsford Club, 1837), i, 43-4 and 84-5.
} 
James VI was eight years old and at a time when Scotland's press output was small, an act of Privy Council was passed charging that no book should be printed without license of the chancellor and commissioners to be chosen by the Privy Council. It was also agreed:

that ther be a register keippit be the Secretar, or his deput, of the licences, and privilegeis to be granted for eschewing of confusion, and that the libertie of the prenting of ane thing be not given to twa Personis at anis. ${ }^{26}$

Over a century later when in 1695 a committee of the Privy Council was considering means to better control and regulate the printing and sale of books, it was ordained that each bookseller of Edinburgh should be compelled to deliver up for approval by the Council exact catalogues of stock to be sold. The clerks of the Council were ordered to keep a list of approved booksellers and their stock. ${ }^{27}$ Many of these booksellers would also have been the major copy holders of the time, but again no register of book traders and their stocks has been found. We might ask how such administrative tasks could have been carried out without some form of register and the circumstantial evidence for its existence is compelling.

\section{An Anatomy of 'particular' Copy Patents}

In early modern Scotland, copyright patents were normally granted in response to applications from potential licensees and generally these requests came in the form of petitions. To begin with these petitions addressed one of the most fundamental aspects of copyright protection, the term. Other factors such as the scope and width of the right granted and the penalties and compensations for breaches were also of huge significance. As noted above, English copyright tended to extend for seven to ten years under the printing patent,

\footnotetext{
${ }^{26}$ RPCS, i, 2, 387; Couper, 'Copyright before 1709', 57.

${ }^{27}$ NRS, PC.1.51, ff. 20, 28.
} 
and in perpetuity for those rights registered with the Stationers' Company. Throughout the period French, German and Italian publishers were often granted short licences of less than five years' duration, France lengthening to ten years in 1700, although the relevant authorities were generally prepared to extend privileges after rights expired. Meanwhile, Dutch copyright tended to be for longer periods of fifteen to twenty-five years. In Scotland, by 1670 , the standard term of copyright for 'particular' works, whether granted to an author, printer, or licensee, was nineteen years, a term closer to Dutch than English or French norms. ${ }^{28}$ The reasons for this specific duration are unclear. The granting of gifts, rights and patents for the period of nineteen years goes back to at least the 1580 s. There are many examples: under the Privy Seal we find tacks (leases) granted in 1583, appointments to crown offices in 1588, and a monopoly for paper making in 1590, all for nineteen years. Commercial patents for processes and inventions were actually more commonly twenty-one years from 1600 to 1660, but the Scottish Parliament's 1661 Act for Erecting of Manufactories provided nineteen years of tax exemptions, and certainly by the 1690 s nineteen-year patents were the norm, including a curious grant in 1699 to James Donaldson, editor of the Edinburgh Gazette, for a brass block process for printing burial letters. ${ }^{29}$ Indeed, in spite of the fact that book copyright terms could extend from as little as six years to the thirty-one years granted to Sir William Alexander for the Psalms in 1627, a consistent and logical approach was taken to the terms granted depending on the circumstances of publication. Reprints, perceived as inferior 'intellectual property', were granted shorter copyright durations. The standard term for reprints was eleven years from the 1670s. The Edinburgh printers George Swintoun and James Glen were granted in 1617 eleven-year

\footnotetext{
${ }^{28}$ Lucien Febvre and Henri-Jean Martin, The Coming of the Book: the Impact of Printing, 1450-1800, translated from the French by David Gerard, ed. Geoffrey Nowell-Smith and David Wootton (N.L.B, 1976), 241; Elizabeth Armstrong, Before Copyright, The French book-privilege system, 1498-1526, (Cambridge University Press, 1990), 16-17; P.G.Hoftijzer, Engelse boekverkopers bij de beurs: De geschiedenis van de Amsterdamse boekhandels Bruyning en Swart, (APA-Holland University Press, 1987), 108. ${ }^{29}$ RSS, viii, 257-8, no. 1577 and 379-80, no.2204; NRS, PS.1.57, f. 77; PS.1. 61, f. 84v; PS. 1. 63, f. 103v; PC.2.27, ff. 201r-202r; RPS, 1661/1/344.
} 
licences to reprint William Guthrie's popular Christian Interest and the many sermons of the minister Andrew Gray. Fully revised editions received a full term copyright, however, as with terms given to the grammarian James Kirkwood for the new editions of his grammar and vocabulary published in the $1690 \mathrm{~s}^{30}$

For specific reason, some new titles also became subject to reduced terms of copyright. Before the 1590s the government awarded short licences to printers such as Robert Lekpreuik (fl. 1561-74) and Alexander Arbuthnet (fl. 1575-85) for fear that important scripture and liturgical printing would not be carried out. The twenty-year licence given to Lekpreuik in 1568 for printing the Geneva Bible, a task he never began, was a salutary warning of the dangers of granting long licences that produced no results, and thereafter short licences of seven or ten years were given for printing bibles, psalms, and catechisms, notwithstanding the generic rights of the king's printer. ${ }^{31}$ Shorter licences were also granted for some works of public utility, such as the ten-year copyright awarded in 1624 to the author and Edinburgh burgess Alexander Hunter for his Treatise on measurement, a guide to agriculture and commerce described in the patent as 'for the benefit of the haill realme', and five-year licence to the printer John Reid to publish Thomas Livingstone's guide to military discipline Exercise of the foot . . . and exercise of the Dragoons in $1693 .{ }^{32}$ This level of public concern did not stretch to school books as seen in the copyright for the prescribed national grammars of Alexander Hume (1611) and David Wedderburne (1632) with terms of twenty and twentyone years respectively. Translations were often subject to shorter licences, such as Sir James Turner's Historicall and Politicall Observations on the War with Hungary, licensed for ten years in 1669. Translations appear to have had less value as literary property. As for the more ephemeral works, copyright for which was rarely worth seeking, the briefest of licences could

\footnotetext{
${ }^{30}$ NRS, PS. 1,100, 305; RPCS, iii, 3, 306; RPCS, iii, 4, 292 and 5, 268; NAS, PC. 2, 26, f. 47v. Mann, Scottish Book Trade, 104-14.

${ }^{31} R S S$, vi, 53, no. 230; RSS, vii, 333-4.

${ }^{32}$ RPCS, i, 13, 418-19; NRS, PC. 2.24, ff. 244v-245r.
} 
follow. Such was the case in 1696 when George Mosman (fl. 1685-1707), printer to the General Assembly of the Church of Scotland, was granted by the Privy Council a one-year licence to the sensational $A$ true relation of an apparitioune, an account by Alexander Telfer of the haunting of a house in Kirkcudbright. ${ }^{33}$

Some aspects of copyright protection, in terminology and breadth of right, remained virtually unchanged throughout the period. One of the first 'particularised' or private copyrights, that given to William Niddrie in 1559, granted him and 'his factouris and assignais, to have onlie the prenting of the saidis volumes' and that no subjects, printers and booksellers 'should tak upoun hand to prent, sell, caus be prentit or sald [them] within this realm'. In one respect the terms of Niddrie copyright are unique in Scottish publishing history. During the licence of ten years, copyright was assured for all other volumes 'that it sal happin him be author or sett furth during the said space', a rather open-ended arrangement explained by the fact that his books represented an official and agreed curriculum. In other respects, however, the terminology is as familiar by 1700 , with some evolutionary developments. Thomas Bassandyne (fl. c.1564-77) and Arbuthnet's Bible licence of 1576 is the first to clearly prohibit other book traders from importing competing editions. ${ }^{34}$ Subsequently, such protection became a standard addition to the discharge to print, reprint, vend or sell, regardless of the likelihood of foreign competition. Bibles at least always offered that possibility from the presses of Holland and England after the Reformation. Meanwhile, there is no evidence that export rights were ever requested or granted in any copyright.

The multi-title, eleven-book patent granted to the Edinburgh printer Robert Smyth in 1599 is the first to indicate monitoring and searching options for a licensee. Yet the 1627 patent awarded to Sir William Alexander for the new Metric Psalms provided a more impressive list

\footnotetext{
${ }^{33}$ RPCS, i, 9, 275; RPCS, ii, 4, 500-1;RPCS, iii, 2, 602, 593; NRS, PC.2.26, ff.90v-91r.

${ }^{34} R S S$, v, pt.1, 143-4; RSS, vii, 12, 94, no. 642; NRS. PS. 1, 43, f.103r.
} 
of supervisory and policing powers. As an influential courtier, co-author with the late king James and by then also Secretary of State, Alexander was given the right, if contraveners were found, 'to sell, bartar and dispose thairvpoune' and to confiscate 'haill workis, tooles and instruments' as well as the offending books. Sheriffs, justices of the peace, bailiffs and constables were to assist him in the policing effort. Smyth's powers were paltry in comparison. ${ }^{35}$ The most comprehensive protections were given to copyright on official business. Nonetheless, it was not until the great forty-one-year monopoly granted to Andrew Anderson in 1671, on his appointment as king's printer, that such powers became controversial and the subject of frequent litigation. ${ }^{36}$ As policing copyright was at the behest of the copy holder, this placed the advantage with the wealthier, royal printers, and especially with Agnes Campbell (fl. 1676-1717), Anderson's widow, who succeeded him in 1676 and was extraordinarily litigious. James Watson, the younger (fl. 1695-1722), Edinburgh printer and bitter rival of Campbell, records in his History of the Art of Printing (1713), the first history of printing in the British Isles, that in 1688 Campbell fell 'tooth and nail' upon those who breached her privileges. ${ }^{37}$

Other aspects of Scottish rights granted are also noteworthy. Sometimes exclusive rights were moderated in some respect. For example, it was made clear that the licensing of Wedderburne's national grammar did not prevent masters of schools using other grammars if they wished. Also, while the bookseller Gilbert Dick's 1618 patent for two 'official' catechisms was the first to add the right to 'distribute throughout the realme', we see an extra

\footnotetext{
${ }^{35}$ NRS, PS. 1.71, 86; PS.1.100, 305. For a list of the titles in Smyth's patents see Mann, Scottish Book Trade, $239-40$.

${ }^{36}$ RPS, 1672/6/158 (11 September, 1672).This relates to the ratification by Parliament of the Anderson patent. It was granted under the Scottish Great Seal in May 1671 but was not recorded in the register. For a detailed account of the subsequent disputes see Alastair Mann, 'Book Commerce, Litigation and the art of Monopoly: The Case of Agnes Campbell, Royal Printer, 1676-1712', Scottish Economic and Social History, (1998), 18, 2, 136-9.

${ }^{37}$ James Watson, A History of the Art of Printing (Watson, 1713), 16; John Lauder of Fountainhall, Historical Notices of Scottish Affairs, (2 vols, Constable, 1848), 2, 866; Fountainhall, Decisions, 1, 494; NAS, PS, 1, 71, 86. Although Watson's is the first history of printing in the British Isles it is based on Jean de la Caille's Historie de L'imprimerie (1689).
} 
'right' stemming from a desire for satisfactory performance in liturgical publishing. This attitude was replicated when Robert Young was awarded the printing rights to the controversial Service Book of $1637 .{ }^{38}$ Conversely, some copyrights obtained in the 1670 s and 1680s only refer to the right to print, confirming not only the more extensive bookselling network throughout Scotland but also that behind the scenes authors were making contracts directly with printers.

A further sophistication is found in the extension of rights to heirs as well as assignees. Assignees were, of course, recognised in the earliest copyright patents. Meanwhile, heirs were first mentioned in the copyrights granted to the king's bookbinder John Gibson in 1599, and the first royal appointment declaring likewise was that of Walter Finlason when he became king's printer in 1628. Finlason succeeded his father, although not as of right. Thereafter, the right of heirs is more commonly declared, although by the 1680 s there is a greater tendency to accept the right of authors' heirs rather than those of printers, at least in grants for 'particular' copyrights. Thus the translator Robert Kirk (1684), and author George Dallas (1695) have copyrights secured for their heirs. Nevertheless, some copy holders, such as the law publisher and bookseller John Vallange, secured impressively comprehensive copyrights with rights conferred on heirs, co-partners and assignees..$^{39}$

Redress or compensation for a breach of copyrights was suggested from the advent of the press in Scotland but it was not until the 1565 copyright granted to Robert Lekpreuik for acts of Parliament and the Psalms of David that we find the first mention of confiscation of offending stock for 'particular' licences. The first generic licence, the patent of Chepman and Myllar of 1507, warned that forbidden trafficking of printings within the gift would result in

\footnotetext{
${ }^{38}$ RPCS, ii, 4, 168-9, 500-1; RPCS, i, 11, 30-31, 643-4; Mann, Scottish Book Trade, 39-40, 107. Wedderburne's rights in terms of exclusivity were reduced in June 1632 from the original rights of 1631.

${ }^{39}$ NRS, PS. 1.71, f. 47r; PS.1.101, f. 120; Lee, Memorial for the Bible Societies, appendix, xii, xxii; RPCS, iii, 8, 414; NRS, PC.2. 25, f.155v; PC. 2.27, ff.248r-249r.
} 
'escheting of the buiks' ${ }^{40}$ This sanction was added to almost every copyright patent down to 1710. From the 1560s fines were also introduced, though always in addition to confiscation, and ranged from $£ 200$ to $£ 2000$ scots. With the larger fines half of the sum could be allocated to the crown or even in some cases to the poor. Imprisonment was not felt an appropriate sanction for abusers of private copyrights - a relatively minor offence. The only instance of a particular licence threatening prison can be found, not too surprisingly, in the terms of the royal grant to Sir William Alexander for the 'new' Psalms of David (1627). Imprisonment was nevertheless an element in some copyright disputes, yet these cases always arose over the rights of the king's printer, notably in 1677 when the Glasgow printer Robert Sanders, the elder (fl. 1661-94), was accused of breaching the general copyright of Agnes Campbell. The breach, according to the pursuer's charge, involved a range of 'New Testament and psalm books ... grammars ... many thousands of catechisms ... [and numerous] books of divinity and school books', all of which were subject to the royal gift. However, the main reason for Sanders' spell in prison was his failure to attend part of the hearing, make his oath before the Council and accept its best efforts at arbitration. In other words, as reflected in the Alexander case, the closer you got to the king and government the greater the sanction for a breach of copyright, or of course contempt. ${ }^{41}$

Assessing the scale, frequency and recipients of such copyrights provides some idea of their pervasiveness and a hint to the respect in which the system was held. As the table in the appendix shows from the 1540 s to 1708 some 188 book titles were provided with particular copyright protection by way of over 90 patents. ${ }^{42}$ Unsurprisingly there is a considerable expansion in patents granted as publishing activity increased from the 1670 s. For probably political reasons, as no doubt also record keeping omission, there are no recipients in the

\footnotetext{
${ }^{40}$ RSS, v, pt.1, 564, no. 1987; RSS, i, 223, no.1546; Dickson and Edmond, Annals of Scottish Printing,7-8.

${ }^{41}$ RPCS, iii, v, 141-2; NAS. PS.1.100, f.305; Mann, Scottish Book Trade, 108-9; Mann, 'Agnes Campbell', 142. Campbell's claim of $£ 20,000$ of damages, opportunistically half to the crown, was rejected.

${ }^{42}$ A list of 'Particular' copyrights so far discovered can be found in Mann, Scottish Book Trade, 235-52.
} 
years 1687 to 1690, as the Revolution built, a Catholic press hovered in Edinburgh and then the Revolution came. The1650s were also empty as not only was a recession in the general book trade evident but Edinburgh printers, such as Englishman Evan Tyler, began to register books with the Stationers' Company. In his case he even departed for London in 1652.

Clearly this number of copyrights represents a small proportion of all printing in Scotland during this period. This figure of particular grants excludes all generic privileges through the Scottish 'printing patent', as well as local licences not ratified by the crown. Also, many printings were too ephemeral or insignificant as literary property to warrant protection in any case. The fee payable when applying for a patent was also a disincentive in such cases. Some copyrights are, however, clearly missing. For example, there appears to be no official record of the 'particular' copyrights acquired separately by Alexander Arbuthnet and Robert Waldegrave, which were later bought by Finlason in 1604 and 1606 respectively, neither of which can be accounted for by the gift of king's printer held by both. There are other more blatant examples: no recorded copyrights for Andrew Hart and Henry Charteris (c.1568-99), neither of whom was king's printer and both of whom were amongst Scotland's most successful and original printer/publishers. In spite of this, some interesting observations can be made, not least of which is that authorswere the recipients of many copyrights - in fact $46 \%$ of recorded recipients were authors, a proportion which increased throughout the period. In Scotland, authors became more important as copy holders than printers. There are also indications that copyright protection was reasonably effective in Scotland by the late seventeenth century, and not so inferior to the more formal English system, given estimates that perhaps $40 \%$ or $50 \%$ of all English printings were not registered with the Stationers' Company. ${ }^{43}$

\footnotetext{
${ }^{43}$ A.W. Pollard, 'Some notes on the history of copyright in England, 1662-1774', The Library (4 ${ }^{\text {th }}$ edition). (1922), 99 and Feather, Publishing, Piracy and Politics, 27.
} 


\section{The 'printing patent' and litigation}

The most valuable monopolies available to Scottish book traders of early modern Scotland were those associated with royal appointments. These provided wide generic copyrights. The most significant of these appointments was the king's or queen's printer, the 'printing patent', which always remained at the behest of the crown and never became subjected, by sale and mortgage, to endless co-partnerships as did the equivalent in England. A continuous line of king's printers for Scotland existed from the 1560s with less certain continuity from 1507 until then. Also, in its handling of this position and associated prerogatives the crown was not always a benevolent force as far as the freedom to print unhindered by restrictive rights to copy was concerned. Early royal appointments, unlike particular copyrights, were for life, but it was only with the appointment of Walter Finlason as king's printer in 1628 that heirs and assignees were recognised. Nonetheless, for this and subsequent appointments all royal printer gifts were for a set period of years. Co-partnerships, hereditary rights and the involvement of assignees were only possible after such positions were limited to a fixed period, a key contrast with England. ${ }^{44}$

The attitudes of royal printers, nevertheless, bring into sharp focus the proprietorial view of copyright before 1710: it increasingly became the concern of courts and of lawyers. Certainly 200 years before, the courts, in the form of the Privy Council, took action in 1509 and 1510 to protect the privileges and copyrights of Walter Chepman concerning the new Brevarium Aberdonense. Chepman issued a complaint that booksellers had been illegally importing England's 'Salisbury use', and the Council issued a warning to a group of merchants to immediately halt such trade in favour of Elphinstone's text. The legal complexities increased

\footnotetext{
${ }^{44}$ NAS, PS. 1,101, 120. For a summary of the history of the privileges of Scottish royal printers see Mann, Scottish Book Trade, 114-22.
} 
markedly from the Restoration. The wide supervisory and generalised copyrights granted in 1671 by Charles II (r.1649-85) and his senior minister the Duke of Lauderdale to Andrew Anderson, royal printer 1671 to 1676 , and subsequently inherited of course by his widow Agnes Campbell, were the cause of major disputes in the book trade of Scotland in the 1670s and 1680s. Anderson, his partners and assignees were not only 'his Majesties . . onlie sole and principall printer', with rights to print all bibles, liturgy and school books, but they were also 'Masters, Directors and Regulators of his Majesties office of Printing', with powers to police imports, prevent printers setting up presses who had not served apprenticeships, and they could, subject to the Privy Council, 'seclude and debarr all others [of the] freedoms and immunities' of trade. The ruling against Hart in 1614 (as noted above) was temporarily forgotten. ${ }^{45}$ Then arose James VII and II's appointment in 1686 of the Catholic James Watson, senior (fl. 1685-7), to the anomalous post of 'household printer'exsting concurrently with that of king's printer, and with a monopoly over all almanacs, even those already in print. This created much consternation in the trade and especially for Agnes Campbell. Nonetheless, the courts showed a remarkable degree of independence in the face of much irrational exercise of royal prerogative. While the Revolution of 1688/9 took care of the post of 'household printer' and James VII (r.1685-88), the Privy Council gradually reduced the sweeping copyrights of Campbell and her supervisory role over the Scottish press, taking it back in stages by 1681 to the privileges enjoyed by Evan Tyler in 1641. Campbell's policing prerogatives were no longer to extend to imports from England, unless specifically in competition with her own existing Bible printings and her apparent power to prevent competing presses from opening was rescinded. Campbell's appeal to the lords of session in the winter of 1682-83 failed and her weak argument for the status quo, that 'one press [was] sufficient' for official documents, was seen by the investigating committee as acting, like her

\footnotetext{
${ }^{45}$ RPS, 1672/6/158; Lee, Memorials for the Bible Societies, appendix no. xxix, 56-61; Dickson and Edmond, Annals of Scottish Printing, 84-5; Mann, Scottish Book Trade, 129-30.
} 
old patent, 'to restrain the liberty of printing too much'. ${ }^{46}$ The fact that George I (r.1714-27) made the absurd appointment of John Baskett, English royal printer, and Robert Freebairn as sole printers to the King in Scotland in 1714, in spite of a valid 1711 warrant that existed in the names of Freebairn, Baskett and James Watson, the younger, confirms the continued and irrational crown interference. This case Watson, the younger v Freebairn, Baskett and Campbell (1713-18) reached the Court of Session, which from the 1680s began to take over competence for book trade disputes from an over-stretched Privy Council. Eventually the House of Lords gave its judgment in 1718 in favour of the 1711 gift. Farce continued to dog the affair when Robert Freebairn became printer to the Old Pretender in the Jacobite rebellion of 1715 , and subsequently was forfeited his share of the gift. ${ }^{47}$

Disputes about copyright privileges in the late seventeenth century centred around two main classes of books: bibles and almanacs. The most prestigious and lucrative rights for religious publishing were of course those connected to the 'bible patent'. But while it was regarded as one of the duties of the royal printer to deliver printed bibles to the nation, both the government and the Church of Scotland were more concerned with issues of supply, and occasionally textual and production quality, than the preservation of restrictive copyrights. The early modern Scottish book trade, let alone a single royal printer, was never able to meet the demand for scripture in this period. Therefore, as seen in various Privy Council rulings in the 1670 s and 1680s, the Bible rights of the royal printer only protected those editions and formats that he or she could keep in print. ${ }^{48}$ Nevertheless, Bible imports from England were also a threat to the royal Bible patent. Campbell regularly complained to the Privy Council

\footnotetext{
${ }^{46}$ Fountainhall, Historical Notices, i, 311, 393; RPCS, iii, 7, 257, 12, 460-1; NRS, Registrum magni sigilli, Register of the Great Seal of Scotland manuscript registers (paper register) [RMS], C3/10. no.343; Lee, Memorials for the Bible Societies, 146; Mann, 'Copyright and illegal activity', 44-46. For the appeal by Campbell which was concluded in January 1683, see Fountainhall, Decisions, i, 205, 424.

${ }^{47}$ NRS, Privy Seal Registers, PS.3/4, 248; RPC, iii, 13, xx; RMS, C3/15 no.388; NAS. Court of Session Papers, Productions and Processes CS29/ box.436.1 (Mackenzie); W.J. Couper 'The Pretender's Printer: Robert Freebairn', Scottish Historical Review, xv, (1917), 106-23. For a full account of the Watson legal battle, see Mann, 'Agnes Campbell',140-1.

${ }^{48}$ For such licences see $R S S$, vii, 94 no.642; NAS. PS.1.43, f.103r; RSS, vi, 53, no.230.
} 
over these incursions. In 1688 she seized octavo bibles at Leith which had been imported from London by the Edinburgh bookseller Alexander Ogston (fl. 1680-90). Ogston was well connected to the legal profession, having received his burgess ticket free in 1680 on the recommendation of the College of Justice and the Lord Advocate, Sir George Mackenzie of Rosehaugh. Regardless, Campbell won the day. The lawyer Sir John Lauder was left to reflect on the meanness of her octavo that was shown to the court to justify her entirely legal actions. ${ }^{49}$ Ironically her Edinburgh press printed a counterfeit London Bible in 1707 looking to take advantage of the trade opportunities that the Union provided. ${ }^{50}$

The disputes over almanacs were even more complicated given that the presses of Aberdeen, Glasgow and Edinburgh were all involved. From a commercial point of view these small, annual, sixteen page, octavo booklets, selling for only $4 \mathrm{~d}$, were the most valuable publishing properties in the late seventeenth century. They carried advertising, a reflection of their mass circulation and linking them to the newspaper revolution that began at the turn of the century. The earliest known almanacs out of Scotland's three printing burghs were Aberdeen (1623), Edinburgh (1632) and Glasgow (1661). ${ }^{51}$ In 1682 and 1683, Robert Sanders of Glasgow and Agnes Campbell each produced separate counterfeit editions of the highly successful 'Aberdeen Almanac'. This Aberdeen edition, compiled with the help of the mathematicians at King's College, had become the market leader since the 1660s. The most infamous case arose in 1684, in which year Forbes, the younger (fl. 1662-1704), with the support of the magistrates of Aberdeen, prosecuted Sanders and Campbell before the Privy Council in Edinburgh. After the case was referred to a committee it ruled in favour of Forbes and Aberdeen. He won his case in law because he was 'in use and possession of printing yeirly

\footnotetext{
${ }^{49}$ Watson, History of the Art of Printing.16; EBR, x, p.392; Lauder, Decisions, i, 496 and Lauder, Historical Notices, ii, 866.

${ }^{50}$ For a discussion of this Bible counterfeit see Mann, 'Copyright law and illegal activity' 52-54.

${ }^{51}$ McDonald, 'Scottish Seventeenth-Century Almanacs', 257-322; Mann, The Scottish Book Trade, 15-16, 1034 and Mann, 'Agnes Campbell', 143-5.
} 
ane almanack as printer of the toun and coledge of Aberdein', and therefore his copyright was sustained. Aberdeen's copyright had also been breached. Sanders had attempted to forge the city arms of Aberdeen which always adorned the almanac, and therefore his offence was viewed as especially devious. Unfortunately for Forbes the drip, drip of counterfeit editions continued over this highly profitable genre. Some consolation was gained by the fact that Campbell also produced various counterfeit editions of Forbes's main competition, the Edinburgh almanac of James Paterson, the authorised Edinburgh edition licensed by the capital from $1684 .^{52}$

\section{Conclusion: a system of repute}

We might ask if authors and printers adhered to and respected the copyright regime of early modern Scotland—-some case studies provide clues. The publishing history of The Works of Sir David Lindsay, the early sixteenth century Scottish poet and dramatist (c.1486-1555), is such a case study with a patent history that began in $1590 .{ }^{53}$ Although Henry Charteris published the first extant edition in 1568 , and commissioned reprints in 1570 s and 1580 s, the first copyright was granted to the king's bookbinder John Gibson in 1590. Following Gibson's death, his son sold the right to Thomas Finlason in March 1606, which was confirmed in a copyright patent of that year. This period was for twenty-five years, thus taking us to 1631. In fact, the printed editions provide a bemusing picture in relation to the right to copy. Firstly, Charteris printed two editions in the 1590s, when Gibson possessed the copyright and must have done so under agreement with the later. Subsequently, during the confused six years between the death of Gibson in 1600, and the sale of his rights by his son to Thomas Finlason, Charteris's son Robert printed two editions, one under licence from the

\footnotetext{
${ }^{52}$ Mann, 'Copyright and illegal activity', pp. 47-52.

${ }^{53}$ For a more detailed account of what follows see Mann, Scottish Book Trade, 110.
} 
heirs of Gibson and one suspiciously anonymous. Finlason then printed his one and only edition in 1610 and, thereafter, during Finlason's life, all editions came from the press of Andrew Hart, who must also have made an agreement with the licence holder. On the death of Finlason in 1628, whose rights were left in the hands of his son Walter, the Aberdeen printer Edward Raban took the opportunity to print his own edition of Lindsay. The heirs of Andrew Hart printed one more edition, in 1630, before the twenty-five-year patent expired. After this date a free-for-all ensued from the print centres of Scotland.

Lindsay was long dead, but what of a living author seeking to protect literary property? The actions of school master James Kirkwood echoes typical copyright concerns. The history of grammar licensing and regulation in Scotland shows that the authorities did not take a consistent line in the licensing of school grammars. Prescription under James VI and I, with a set national grammar, was followed by recommendation under Charles I and then scholastic freedom under Charles II, although protecting copyright was no less important. ${ }^{54}$ Kirkwood's grammar, published in three parts from 1674 to 1676, was subject to pirating, abridgement and copyright abuse in spite of the nineteen-year licence granted to him in 1674 . He was so concerned that he delivered a supplication to the Privy Council in 1677 requesting a revised copyright with more rigorous punishments for abusers. That year he was granted fresh copyrights of nineteen years for a one volume edition of his Grammatica Facilis and also for his Rhetoricae Compendium, each with the penalty of the very large fines of 2000 merks (or $£ 1300$ ) for pirates. Later, as the copyright terms were due to expire, Kirkwood was granted in 1695 new nineteen year licences for revised editions of both his grammar and his vocabulary. These were clearly new editions as the standard period for reprints was eleven years. But the fact that no subsequent Kirkwood copyright breach is mentioned in the Council records before 1708 suggests these measures were effective. Being caught pirating such works could

\footnotetext{
${ }^{54}$ For grammar publishing see Mann, The Scottish Book Trade, 153-4.
} 
be potentially disastrous for printers, a clear deterrent. The penalties protecting Kirkwood's copyrights, which were so severe he may have had friends in high places, declare that contraveners 'make up whatever loss and damage [he] may sustain', as well as confiscation of the offending printed stock and the fine. ${ }^{55}$ The proof being in the pudding, these details confirm, then, a pragmatic and practical approach to copyright. Printers both respected literary property, and sold and acquired copyrights, yet also they exploited commercial opportunities when they presented themselves. Furthermore, the copyright for a deceased author was less likely to be policed with rigour.

The legal profession of pre-Union Scotland was clearly at the heart of copyright regulation, interpretation and litigation but also central to an expanding culture of authorship which intensified in the course of the seventeenth century. Evidence for this is widespread, and yet the sense of detail and purposefulness is confirmed in an agreement of 1681 between Sir James Dalrymple of Stair (1619-95), President of the Court of Session, and Agnes Campbell herself, over the printing of Stair's Institutions of the Law of Scotland (1681). This agreement was made the month before a successful application for copyright by the author. Stair was contracted to deliver up his manuscript to Campbell, to give the text only to her and to allow her exclusive reprint rights. Meanwhile, Campbell agreed to print the text in English roman, 'conform to the printed sheet subscribed by both parties', to print six sheets per hour and to deliver out no copies without approval. Written copies and printed copies were to be kept 'under lock and key' under penalty. A number of copies were to be delivered for the author's use, half well bound in leather, the other half gilded, and 'so soon as the samen are presented whensoever [Stair] shall call for the samen under the pain of 400 pounds scots money as the Liquidate pryce thairof by consent' ${ }^{56}$ Finally, the printer had to agree to use the privilege, not print the book abroad and not allow others to produce it on her behalf. Printer and author

${ }^{55}$ RPCS, iii, 4, 292; RPCS, iii, 5, 211 and 268; NAS. PC2/26, 47v.

${ }^{56}$ NRS, PS. 3.3. ff.336-7; NRS, Earl of Stair Papers, GD. 135, 2762/2. 
content, publication soon arrived and the law of contract and of copyright came together to produce a highlight of publishing in early modern Scotland and evidence of a broadly fit for purpose copyright system before the Act of Anne of 1710. Yet this is an impression to be challenged or endorsed by future research. The manuscript registers of the Privy Seal from the late sixteenth century which record early copyrights, and the vast Court of Session records from the seventeenth century, where judgments on book trade cases became a growing competence, require exhumation and analysis. Contracts like that of Dalrymple and Campbell must exist in estate papers and amongst the volumes of deeds in the National Records of Scotland in Edinburgh. Scotland's copyright historiography of the early modern period may be a callow youth but it need not always be so.

Appendix

Number of 'Particular' Copyright Grants in Scotland, 1540-1708 ${ }^{57}$

Decades Patents Titles Authors Printers/ Licensees Editors

\footnotetext{
${ }^{57}$ Sources RPCS (Privy Council), PS (Privy Seal) and RPS (Records of the Parliaments of Scotland). Adapted from Mann, Scottish Book Trade, Table 1, 112.
} 
Booksellers

\begin{tabular}{|c|c|c|c|c|c|c|}
\hline $1540 \mathrm{~s}$ & 1 & 1 & - & 1 & - & - \\
\hline $1550 \mathrm{~s}$ & 1 & 11 & 1 & - & - & - \\
\hline $1560 \mathrm{~s}$ & 4 & 5 & - & 3 & 1 & - \\
\hline $1570 \mathrm{~s}$ & 5 & 16 & - & 3 & 2 & - \\
\hline $1580 \mathrm{~s}$ & 1 & 3 & - & 1 & - & - \\
\hline $1590 \mathrm{~s}$ & 4 & 18 & - & 3 & 1 & - \\
\hline $1600 \mathrm{~s}$ & 4 & 26 & 1 & 2 & 1 & - \\
\hline $1610 \mathrm{~s}$ & 7 & 13 & 1 & 5 & 1 & - \\
\hline $1620 \mathrm{~s}$ & 3 & 3 & 2 & - & 1 & - \\
\hline $1630 \mathrm{~s}$ & 3 & 3 & 2 & - & 1 & - \\
\hline $1640 \mathrm{~s}$ & 1 & 3 & 3 & - & - & - \\
\hline $1650 \mathrm{~s}$ & - & - & - & - & - & - \\
\hline $1660 \mathrm{~s}$ & 7 & 7 & 2 & 2 & 2 & 1 \\
\hline $1670 \mathrm{~s}$ & 11 & 14 & 6 & 4 & 1 & - \\
\hline $1680 \mathrm{~s}$ & 16 & 23 & 15 & 1 & - & - \\
\hline $1690 \mathrm{~s}$ & 16 & 27 & 4 & 7 & 4 & 1 \\
\hline $1700 \mathrm{~s}$ & 9 & 14 & 5 & 3 & - & 1 \\
\hline Totals & 94 & 188 & 43 & 34 & 15 & 3 \\
\hline$\%$ & 100 & & 46 & 36 & 16 & 2 \\
\hline
\end{tabular}

